\title{
TWO-SIDED MARKETS: AN APPLICATION TO MOBILE TERMINATION IN SOUTH AFRICA
}

\author{
Nicola Theron* \\ University of Stellenbosch \\ nicola@econex.co.za \\ Johann van Eeden" \\ Econex Pty Ltd \\ johann@econex.co.za
}

April 2011

\begin{abstract}
The concept of a two-sided market has received increased attention in the academic literature of late. In this paper we argue that the market for call termination is an example of a two-sided market. We apply the concepts of a two-sided termination market to the current attempts by ICASA to reduce mobile termination rates through regulation. We also deal with the concepts of significant market power (SMP) and established significant market power (ESMP), and show that the traditional thinking around market power has to be adapted when one deals with two-sided markets. More specifically, we analyse these concepts by looking at the position of Cell C, a smaller player in the mobile market in SA. We show that market power (and appropriate pro-competitive remedies) in call termination markets cannot be established without considering the origination (retail) market - the other side of the two-sided market.
\end{abstract}

Keywords:

Mobile termination, mobile interconnection, two-sided markets, telecommunications, ICASA

\footnotetext{
* Dr Nicola Theron is an extraordinary senior lecturer in the Department of Economics at the University of Stellenbosch, South Africa and director of $\varepsilon$ conex.

\# Mr Johann van Eeden is a senior economist Econex, Stellenbosch, South Africa.
} 


\section{INTRODUCTION}

The concept of a two-sided market has received increased attention in the academic literature of late. It appears that some consensus has emerged on the main features of such markets, but the implications for regulation are not well understood. In this paper we argue that the market for call termination is an example of a two-sided market. The telecommunications sector in South Africa is regulated by both the Electronic Communications Act (ECA) and the Competition Act. It is important for the respective regulators - ICASA and the Competition Commission - to take cognisance of the two-sided nature of such markets. We apply the concepts of a two-sided termination market to the current attempts by ICASA to reduce mobile termination rates through regulation. We also deal with the concepts of significant market power (SMP) and established significant market power (ESMP), and show that the traditional thinking around market power has to be adapted when one deals with two-sided markets. More specifically, we analyse these concepts by looking at the position of Cell C, a smaller player in the mobile markets in SA. We show that market power (and appropriate pro-competitive remedies) in call termination markets cannot be established without considering the origination (retail) market - the other side of the two-sided market.

\section{2. \&CONOMICS OF TWO-SIDED MARKETS}

Important contributions on the economics of two-sided markets include Rochet and Tirole (2003), Caillaud and Julien (2003) and Wright (2004). In these articles the central features of a two-sided market have been analysed. In a summary article by Rochet and Tirole ('Two sided Markets: A Progress Report' (2005:2)) they state the following:

Two sided (or more generally multi-sided) markets are roughly defined as markets in which one or several platforms enable interactions between end-users, and try to get the two (or multiple) sides 'on board' by appropriately charging each side. That is, platforms court each side while attempting to make, or at least not lose, money overall.

Some authors, such as Valetti (2006), prefer to call such markets 'two-sided' platforms. In the words of Valetti (2006:64):

The term 'two sided platforms' (2SPs) refers to products and services that must be used by two (or more) groups of customers to be of value to them. The 'platform' enables interactions between the different 'sides', trying to get the two sides 'on board', and charging each side.

This feature of two 'distinct groups of customers', is a recurring theme in the relevant academic literature. Typically, the demands of each of these distinct groups are dependent and subject to economies of scale. In other words, the more consumers there are on the one side, the more participants the platform can 'attract' on the other side. This feature is obvious when one looks at media markets - the more readers (listeners) there are, the more utility is derived from advertising and the higher the advertising rates that the platform can charge. Therefore the volume of transactions between end-users depends on the structure and not on the overall level of fees charged by the platform. Another important feature of such markets is that an end-user in a two-sided market does not internalise the welfare impact of his use of the platform. When such positive externalities exist which are not internalised by users, the need for a platform 
arises.

The question that will be addressed in this paper is: what is the implication for regulation of such markets? An interesting example is cases of e.g. abuse of dominance and the assessment of market power in typical two-sided markets. One example is a ticket distributor, where a central platform brings together two groups of customers: event organisers and ticker buyers. Recently, the case of one such firm, TicketMaster, has been analysed by a number of competition authorities (including the UK, Ireland, Sweden and Singapore).

In one-sided markets the price level is the most important consideration, as market power is defined as the ability to sustain prices above the competitive level. In a two-sided market, it is not only the price level that is important but also the price structure. One has to look at the relative price between the two sides and importantly the ability of each side to constrain the price-setting behaviour of the other side.

\section{CALL TERMINATION AS A TWO-SIDED MARKET}

Having considered the central features of a two-sided market, the relevant question is whether mobile markets can be described as two-sided. Esselaar and Weeks (2008:1) stated that:

In this paper we argue that mobile termination must be understood in the context of a two sided market for incoming calls. Whether this qualifies strictly as a two sided market is still open to debate, and we are not able to answer this conclusively here.

However, there seems to be enough evidence from the literature to indicate that specifically termination markets can be described as two-sided (see Valetti, 2006). Also, regulatory authorities have recently noted the two-sided nature of termination markets. An example is New Zealand, where the theory of two-sided markets gained prominence during a case on mobile termination handled by the New Zealand Commerce Commission. Both Vodafone NZ and Telekom NZ argued for the application of the principles of a two-sided market in that case. The New Zealand Commerce Commission did not accept all the arguments, although it did acknowledge the two-sided nature of the termination market. The main areas of difference related to the implications for regulation.

In the recent round (2010) of termination rate regulations by ICASA, the South African regulator explicitly accepted the two-sided nature of telecommunications markets. In the Explanatory Note for the draft call termination regulations (2010a:6), ICASA stated the following:

The two sided nature of the market arises because of the interdependence between calling and called parties - with both sides benefiting from the other. Calling parties benefit from having more people connected to a network that they can call, and called parties benefit from being able to receive calls. The Authority notes that it is selfevident that a market for wholesale call termination cannot exist without a market for call origination.

However, similar to the New Zealand Commerce Commission, the South African authorities go on to conclude that the two-sided nature of the market does not necessarily restrain the market power of firms in their termination markets:

The implications for the assessment of market power and the regulation thereof are therefore the important issues and these will be dealt with in detail below. 


\subsection{Market definition}

Substitutes for a good or service are typically identified according to the so-called SSNIP (small but significant non-transitory increase in price) test (see explanation for the SSNIP test in the appendix). In competition economics a market constitutes that particular set of products and geographic area that can potentially be monopolised by the firm under investigation (Geroski, 1998:681 and Massey, 2000:328). This market, in turn, is used to investigate market power, i.e. the firm's actual capacity to monopolise. This involves identifying

(i) all firms selling potential substitutes for the products of the firm under investigation and

(ii) all firms offering these potential substitute products in other geographic areas and reasonably capable of potentially providing the product in regions where the firm under investigation is operating.

The focus, as Motta (2005:102) notes, is on identifying those firms whose operations constrain anti-competitive behaviour by the firm under investigation.

If one applies this test to the 'products' investigated in ICASA's draft wholesale call termination regulations, namely, call termination on respective networks, then it would seem that there are no demand-or supply-side substitutes. If a hypothetical monopolist were to increase the mobile termination rate (MTR) on its own network by a small but significant amount, the other operators (be they fixed or mobile) seeking termination will have no other substitutes to switch to. But it was argued above that the SSNIP test is not strictly applicable in two-sided markets. The literature shows that users on one side make decisions that affect users on the other side, and that it is the price structure rather than the price level which is important. Defining each termination market as a separate market with no constraints on pricing power may not reflect the true nature of these markets, as it ignores the other side - the origination market.

\subsection{Call termination}

In our primary case of interest, the ICASA regulation of termination rates, we concentrate our analysis on the call termination market. A wholesale mobile call termination market is that space where one mobile operator sells access to other mobile or fixed-line operators who seek termination of calls on the former's network. ICASA states in its explanatory document (2010a:v) that:

... no effective functional demand-side alternatives currently exist to call termination on each provider's network. Furthermore, as there is no technological or commercial mechanism for alternative providers to offer call termination on another licensee's network, the consideration of wholesale supply-side substitution does not expand the market.

This conclusion appears to be in line with economic theory up to this point. However, market definition is not an end in itself and should be done for the purpose of assessing the ability of a given firm to exercise market power in that particular market and related markets.

In telecommunications, the termination market exists only because there is an origination market. Furthermore, there is demand for both call origination and call termination from two different sets of consumers when a single call from one network to another is considered. Analysing these markets in isolation leads to markets that are defined too narrowly, as the other side of the market is not taken into consideration. Economists argue that rather than starting 
with an SSNIP test and trying to define sharp boundaries of a market in cases of two-sided markets, an alternative would be to start with the whole array of products under investigation (i.e. call origination, call transit and call termination). This will avoid the exercise of market definition and allow the analyst (or regulator) to delve directly into the economic problem at stake (see Valletti, 2006:69).

The ICASA approach seems to recognise that market definition is only a first step in the analysis of market power. As stated by ICASA in the explanatory note (p. 2):

The process of defining a market definition is not an end in itself. Markets are defined in order to assess whether competition is effective and whether any party has Significant Market Power ('SMP') in a particular market.

This is important, as the pro-competitive measures are aimed at addressing the issue of SMP and the exercise thereof. If one relies too heavily on the SSNIP test, markets will be defined narrowly and the findings of SMP will follow from this structural definition. However, if one starts with the whole set of interlinked products; SMP may not automatically follow (Valletti, 2006:69).

\section{SIGNIFICANT MARKET POWER (SMP) AND ESTABLISHED SIGNIFICANT MARKET POWER (ESMP)}

To ascertain whether regulation of MTRs is necessary, ICASA had to determine whether all mobile network operators have market power (or indeed in the wording of the ECA, significant market power) in their respective termination markets. It was already stated above that it is generally assumed that there are separate relevant termination markets. The more interesting issue is whether Mobile Network Operators (MNOs) as the only seller of termination in such markets have market power or indeed have SMP.

\subsection{SMP classification applied by ICASA}

ICASA based its assessment and classification of significant market power (SMP) on the criteria set out by the ECA. Significant market power (SMP) with regard to a given licensee or class licence is defined in Section 67(5) of the ECA as follows:

"A licensee has significant market power with regard to the relevant market or market segment where the Authority finds that the particular individual licensee or class licensee -

a) is dominant;

b) has control of essential facilities; or

c) has a vertical relationship that the Authority determines could harm competition in the market or market segments applicable to the particular category of licence".

Furthermore, it is implied by the definitions of the ECA that dominance is meant to have the same meaning as that which is determined by section 7 of the Competition Act. In accordance with the Competition Act a firm is dominant if:

- $\quad$ it has at least $45 \%$ of that market;

- it has at least $35 \%$, but less than $45 \%$, of that market, unless it can show that it does not have market power; or

- it has less than $35 \%$ of that market, but has market power" 
A strict application of the criteria listed in section 67(5) of the ECA (and the accompanying definition of dominance in the Competition Act) would lead one to conclude that a particular firm has significant market power in its own wholesale termination market due to the narrow definition applied. More specifically, each licensee will automatically have $100 \%$ of its own wholesale termination market. However, this approach focuses very narrowly on market shares and does not take into consideration various other criteria that are also important in determining the extent to which market power exists and can be exercised in a given market. This is discussed in the section that follows.

\subsection{SMP classification: additional criteria to be considered}

The criteria set out by the Electronic Communications Act ( $(C A)$ oblige ICASA to apply a simplistic view of SMP in a particular market. This is not the case in other jurisdictions. For example, the $\varepsilon U$ guidelines for the assessment of SMP stress that large market shares might only be an indication of a dominant position and that a thorough and overall analysis of the relevant market should be conducted before concluding on the existence or not of SMP (European Commission, 2002). Some of the criteria listed in this regard include the following:

- Overall size of the undertaking

- Control of infrastructure not easily duplicated

- Technological advantages or superiority

- Absence of or low countervailing buying power

- Easy or privileged access to capital markets/financial resources

- Product/services diversification (e.g. bundled products or services)

- Economies of scale

- Economies of scope

- Vertical integration

- A highly developed distribution and sales network

- Absence of potential competition

- Barriers to expansion

Clearly, the preceding list includes a number of factors in addition to market shares that could act to determine SMP in a given market (these can be further explained by Oftel (2002) - the previous UK Office of Communications). For example, the overall size of the undertaking relative to that of its competitors is important in determining the extent to which market shares in a particular market are relevant in determining the existence or not of SMP. This point is also acknowledged in the ICASA (2010a) explanatory note (p. 34):

Whether the operator (in either the wholesale and related downstream retail market) may influence the extent to which it can use countervailing buying power to constrain wholesale call termination rates offered by other licensees.

Areas where the relative size of the undertaking becomes important include economies of scale, finance, purchasing, production capacities, and distribution and marketing. Importantly, it is 
also noted that the advantages related to the relative size of an undertaking can accrue in part due to activities outside the market under consideration. Larger mobile operators would typically display economies of scale both in the wholesale call termination and mobile retail markets. Furthermore, economies of scale are not limited to the production of a given good or service, but often extend to include supporting services such as distribution and sales. Larger competitors typically have well-developed distribution systems that are costly to replicate and maintain. These systems also take significant time and investment to replicate and place larger competitors at a distinct advantage to smaller competitors and new entrants.

Control of infrastructure not easily duplicated is another factor closely related to the overall size of the undertaking and could manifest itself in activities outside the market under consideration. Again, the relative position enjoyed by other licensees in markets outside the wholesale call termination market would be important in determining how this factor interacts with market shares in the wholesale call termination market in determining the extent of market power. In the broader mobile telecommunications market this could manifest itself by way of technological advantages or superiority, creating an advantage over competitors and constraining their market power even in a market where they have a dominant market share. Access to financial markets could also differ between competitors and determine the extent to which they are able to fund infrastructure developments, increase scale or expand their sales and distribution networks. In this regard larger and existing competitors will tend to have an advantage over smaller entities or new entrants.

It is clear that a number of factors in addition to market share as calculated for a very narrowly defined market should be considered when determining if a given entity has SMP or not. These factors are often very closely linked to the size and nature of the overall undertaking and not restricted only to the market for which market shares have been defined. As is evident from the preceding discussion, the position of larger undertakings in related markets could have important repercussions for the extent to which market power can be exercised in a narrowly defined market such as the wholesale call termination market.

In its explanatory note accompanying the draft wholesale call termination regulations ICASA (2010a) does recognise that one has to look at a range of criteria to determine competitiveness in both the retail and wholesale markets in order to make a finding of SMP. This is based on the assumption by ICASA that call termination is a two-sided market. ICASA therefore also analyses the following factors in both the wholesale and retail markets:

- Market share of existing firms;

- Actual and potential competitors;

- Level, trends in concentration and history of collusion;

- Overall size of each of the market participants;

- Control over essential facilities;

- Impact of technological advantages or superiority of a given market participant;

- Firms' access to capital markets and financial resources;

- Dynamic market characteristics of the market;

- Economies of scale and scope;

- Nature and extent of vertical integration; 
- Market and regulatory barriers to entry; and

- Countervailing market (or buying) power.

These aspects have to be considered by ICASA under section 67 of the ECA in any analysis of the effectiveness of competition. However, in the current process, ICASA generally finds that an analysis of most of these factors in the retail markets has little, if any, impact on competitiveness in the wholesale call termination market (2010a:31).

\subsection{Established Significant Market Power (ESMP)}

The term 'established significant market power' or ESMP does not appear in the 2005 ECA but is introduced in the ICASA (2010a) explanatory note for the draft call termination regulations and the actual draft regulations (ICASA, 2010b). While a licensee with SMP is defined as one that is either

a) 'dominant;

b) has control of essential facilities; or

c) has a vertical relationship that the Authority determines could harm competition in the market or market segments applicable to the particular category of licence',

a licensee with ESMP is defined as 'A licensee that held a (PSTN) and (MCTS) licence and has a market share of greater than $10 \%$ in the downstream markets as of June 2009'. Importantly, classification as an ESMP implies a variety of additional regulatory constraints, the most notable of which is a defined (reduced) glide path for mobile termination rates charged on the operators' respective wholesale termination markets.

The concept of ESMP has to be distinguished from the concept of significant market power. It is also important to understand that market share benchmarks represent only one criterion in assessing market power, or indeed SMP in any market properly defined. It was explained in the previous section that other criteria that should be used (according to the European Commission Guidelines on SMP) include the overall size of the undertaking, control of infrastructure, etc. Similar criteria are also listed under section 6(b)(ii) of the ECA, which should be considered together with market share when analysing the effectiveness of competition. This is in recognition of the fact that a position of dominance (or of market power) cannot derive from one criterion alone, but from any combination of relevant criteria.

Market share alone can therefore not be used to determine SMP. The first problematic aspect with the definition of ESMP is that it is defined only with reference to a benchmark percentage (a market share of greater than $10 \%$ in the downstream markets at a given date). Apart from the fact that $10 \%$ is an arbitrary figure (based on no evidence or precedent), this approach should also be rejected as ignoring the real economic question, i.e. the ability to exercise market power and to act anti-competitively.

While this is not clear from the ICASA (2010b) draft regulations or the discussion document, it appears that the relevant market shares were determined based on the number of customers rather than by originated voice traffic or market revenues, as this is the only criterion which would result in three mobile licensees having ESMP (see TABLE $\mathbf{1}$ ).

This follows directly from the fact that market share by voice traffic and market share by revenue allocate only a $9 \%$ market share to the third licensee at June 2009. This shows one of the fallacies of a structuralist approach of using market shares measured in just one part of a two- 
sided market. The difference between $9 \%$ and the benchmark of $10 \%$ is also somewhat arbitrary in choosing a level for ESMP.

\section{TABLE 1: Retail mobile market shares, by total customer connections, originated voice minutes, and revenues, as at June 2009}

\begin{tabular}{lccc}
\hline & $\begin{array}{c}\text { Market share by } \\
\text { customers }\end{array}$ & $\begin{array}{c}\text { Market share by } \\
\text { originated voice } \\
\text { traffic }\end{array}$ & $\begin{array}{c}\text { Market share by } \\
\text { market revenues }\end{array}$ \\
\hline Licensee 1 & $54 \%$ & $55 \%$ & $55 \%$ \\
Licensee 2 & $32 \%$ & $36 \%$ & $36 \%$ \\
Licensee 3 & $14 \%$ & $9 \%$ & $9 \%$ \\
\hline
\end{tabular}

Source: ICASA explanatory note on draft call termination regulations (2010a)

Whereas ICASA's definition of SMP makes reference to the criteria applied in the Competition Act of 1998 and considers factors such as the control of an essential facility, ESMP is not arrived at in a similar fashion. The only economic criteria applied refer to the class of licence held (PSTN and MCTS) and the market share in downstream markets (presumably retail mobile or retail fixed-telephony services). Furthermore, while mention is made of market share when defining ESMP licensees, no economic justification is given for the choice of a $10 \%$ market share threshold to determine ESMP classification. Importantly also, this classification does not follow directly from international best practice.

For example, عU criteria on assessing SMP state that

Although a high market share alone is not sufficient to establish the possession of significant market power (dominance), it is unlikely that a firm without a significant share of the relevant market would be in a dominant position. Thus, undertakings with market shares of no more than $25 \%$ are not likely to enjoy a (single) dominant position on the market concerned. In the Commission's decision making practice, single dominance concerns normally arise in the case of undertakings with market shares of over $40 \%$, although the Commission may in some cases have concerns about dominance even with lower market shares, as dominance may occur without the existence of a large market share (European Commission, 2002:15).

Hence, single-firm dominance SMP is typically only witnessed in markets where the firm in question holds a market share in excess of $40 \%$. However, even in these instances, market share in itself is not seen as sufficient to indicate the existence of SMP.

Lastly, it is important to note that the definition applied by ICASA to determine ESMP licensees refers to market share and position within retail markets (fixed and mobile), while some of the most important 'pro-competitive' remedies applied to these licensees (specifically price control of termination rates) are focused specifically on their operations in the wholesale market (ICASA, 2010b). Put differently, remedies in wholesale markets are being determined by market share in retail markets.

While the economic justification for the choice of a $10 \%$ market share threshold in downstream markets is still not immediately apparent, the definition applied by ICASA with regard to ESMP licensees is an implicit acceptance that a licensee's competitive position in retail markets is of concern when determining that same licensee's competitive position in the upstream wholesale 
call termination market. This implies that the retail market is indeed of particular concern in discussions surrounding competition and countervailing buyer power in the wholesale call termination market. This is in line with economic theory on two-sided markets, which points out that an examination of market shares $(100 \%)$ in termination markets tells only one side of the story.

\subsection{Presence of Countervailing Buyer Power (CBP) in wholesale termination markets}

In its explanatory note on draft call termination regulations, ICASA (2010a:22) defines countervailing buyer power as follows:

'Countervailing Buying Power (CBP) exists when a particular purchaser (or purchaser group) of a product is sufficiently important to its supplier to influence the price charged for that product.'

CBP therefore refers to the relative strength that a particular buyer has in its negotiations with the prospective seller of that product. In the call termination market this will naturally refer to the licensee on whose network the call is being terminated (the seller of call termination) and the licensee from whom the particular call originates (the buyer of call termination). Also, because transactions typically take place on a wholesale basis as opposed to call by call, the buyers and sellers will be those of wholesale call termination and not simply call termination.

Given that each MNO has been adjudged to possess SMP with regard to its own wholesale termination market (the result of a $100 \%$ market share in a particular wholesale call termination market), CBP is an important determinant in constraining the extent to which SMP can be exercised on a given wholesale termination market, and, importantly, to what extent an MNO can act (and price) independently from the rest of the market. This is also confirmed by academics such as Valetti (2006:74):

Countervailing buyer power (i.e. bargaining, negotiations) should therefore be taken into account when analysing the wholesale market for incoming calls in order to determine the presence of SMP.

It was already argued above that it is not accurate to infer SMP from market shares alone, and CBP is an important determinant of whether a mobile network operator (MNO) has SMP or not.

In ICASA's discussion on CBP the percentage of mobile and fixed call termination minutes purchased by the respective mobile licensees are used as departure point to determine to what extent the various mobile licensees are able to exercise CBP on another operator's wholesale call termination market. These values are contained in TABLES 2.7 and 2.8 of the ICASA (2010a: 40) explanatory note. While the number of call termination minutes purchased is undoubtedly an important aspect in CBP determination, it should also be considered that in the broader market for wholesale call termination in South Africa all mobile and fixed licensees are both buyers and sellers of call termination. This follows directly from the fact that licensees are both call originators and call receivers. Furthermore, termination minutes purchased are an integral part of an operator's business, as in the absence of call termination agreements there can be no offnet calls. The importance of off-net calls (and call termination agreements) is even more pronounced in the case of a smaller operator in that a larger percentage of calls originating on the smaller network will be of an off-net nature compared to the call composition of the larger operators. 
TABLE 2: Proportion of mobile terminating minutes purchased and sold by each MNO licensee, January to June 2009

\begin{tabular}{lccc}
\hline & $\begin{array}{c}\text { Percentage of mobile } \\
\text { call termination } \\
\text { minutes purchased }\end{array}$ & $\begin{array}{c}\text { Percentage of mobile } \\
\text { call termination } \\
\text { minutes sold }\end{array}$ & $\begin{array}{c}\text { Difference (percentage } \\
\text { of minutes sold minus } \\
\text { percentage of minutes } \\
\text { purchased) }\end{array}$ \\
\hline Licensee 1 & $34.7 \%$ & $43 \%$ & $8.3 \%$ \\
Licensee 2 & $30.5 \%$ & $42 \%$ & $11.5 \%$ \\
Licensee 3 & $10.8 \%$ & $14 \%$ & $3.2 \%$ \\
\hline
\end{tabular}

Source: $\quad$ Adapted from TABLES 2.3 \& 2.7 of ICASA explanatory note on draft call termination regulations (2010a).

TABLE 2 shows the percentage of total mobile call terminating minutes purchased and sold by each of the mobile licensees. As can be seen from TABLE 2 (columns two and three), the relative percentage of mobile termination minutes purchased and sold by the larger licensees far exceeded that which is accounted for by the smallest licensee (licensee 3). This skewed distribution is even more pronounced in the case of mobile call termination minutes sold (shown in column three of TABLE 2 and evidenced by the more pronounced difference in column four of TABLE 2 for the two largest licensees). As explained above, in general, this places larger licensees in a much stronger position during termination negotiations compared to smaller licensees. (Note that TABLE 2 does not represent the mobile call termination minutes purchased and sold between two specific mobile operators, but rather the percentage of all mobile call termination minutes purchased and sold by a given mobile operator. However, the data contained in TABLE 2 does give a good indication of the relative bargaining position held by different mobile operators in call termination negotiations).

TABLE 3: Proportion of fixed terminating minutes purchased by each licensee, January to June 2009

\begin{tabular}{lc}
\hline & $\begin{array}{c}\text { Percentage of fixed call termination minutes } \\
\text { purchased }\end{array}$ \\
\hline Licensee 1 & $49.7 \%$ \\
Licensee 2 & $33.2 \%$ \\
Licensee 3 & $16.8 \%$ \\
Licensee 4 & $0.1 \%$ \\
Licensee 5 & $0.1 \%$ \\
Other licensees & $0.1 \%$ \\
\hline
\end{tabular}

Source: ICASA explanatory note on draft call termination regulations (2010a)

Similarly, in the case of fixed termination minutes purchased, the larger mobile licensees would have a distinct advantage in negotiations compared to smaller licensees, because of the large percentage of fixed-call termination minutes purchased by these operators. The proportion of fixed termination minutes purchased by each licensee is shown in TABLE 3 . In terms of fixed-call termination minutes sold, Telkom remains by far the dominant player, with $98 \%$ of fixed-call 
minutes terminated on its network (based on ICASA data).

Another important aspect to consider with regard to the extent of CBP that can be exercised is the presence of a particular licensee in the downstream retail market. By way of its definition of established SMP (ESMP) licensees ICASA implicitly contends that the retail market is of importance when determining the extent to which SMP can be exercised in a particular wholesale termination market. While it should again be emphasised that it does not follow directly from economic logic or competition best practice that a $10 \%$ market share as such should have any particular competitive implications, the same cannot be said for market shares in excess of $30 \%$ and $50 \%$, as is the case for the two largest mobile licensees in the South African retail market.

\section{TABLE 4: Retail mobile market shares, by total customer connections, originated voice minutes, and revenues, as at June 2009}

\begin{tabular}{lccc}
\hline & $\begin{array}{c}\text { Market share by } \\
\text { customers }\end{array}$ & $\begin{array}{c}\text { Market share by } \\
\text { originated voice } \\
\text { traffic }\end{array}$ & $\begin{array}{c}\text { Market share by } \\
\text { market revenues }\end{array}$ \\
\hline Licensee 1 & $54 \%$ & $55 \%$ & $55 \%$ \\
Licensee 2 & $32 \%$ & $36 \%$ & $36 \%$ \\
Licensee 3 & $14 \%$ & $9 \%$ & $9 \%$ \\
\hline
\end{tabular}

Source: ICASA explanatory note on draft call termination regulations (2010a)

(TABLE 4, which replicates TABLE 2.5 in the ICASA (2010a) explanatory note, contains calculated market shares for mobile licensees as at June 2009). Depending on the exact classification used, Licensee 3 (Cell C) possesses only between $9 \%$ and $14 \%$ share of the downstream retail market, while Licensee 1 (Vodacom) accounts for between $54 \%$ and $55 \%$ of the market, and Licensee 2 (MTN) for between $32 \%$ and $36 \%$. Again, the strong position of the two largest licensees in the retail side of the South African retail market has afforded them a much stronger position in historic termination agreements and implied that wholesale call termination rates could not be set efficiently with respect to either the smaller licensees' cost structure at the time or the necessary impetus needed for further growth in the market of a smaller competitor.

The three major channels through which the larger operators (both fixed and mobile) are able to leverage their larger size and achieve significant CBP in smaller operators' wholesale termination markets are the following:

1) Threat not to interconnect and threat to discriminate;

2) Threat to withhold interconnection payments and

3) Degrade or increase the price of non-termination services. These are also highlighted in the ICASA explanatory note for draft call termination regulations.

The threat not to interconnect and the threat to discriminate can occur both during the initial negotiations of an interconnection agreement and when an existing interconnection agreement is re-negotiated. ICASA rightly contends that because ECA provisions and regulatory principles require all licensees to interconnect upon request and prohibit discrimination between licensees on technical grounds, no licensee can threaten not to interconnect at all or discriminate. However, there remains a threat to delay the finalisation of interconnection agreements, which would have very much the same net results over the short term as the threat not to interconnect at all. The threat to delay interconnection payments is closely tied to the threat not to 
interconnect or the threat to delay interconnection: smaller licensees are heavily dependent on the ability to interconnect to larger licensees.

The threat to degrade or increase the price of non-termination services is another threat that can be considered credible in the South African context. Cell C (the smallest South African licensee) not only interconnects with larger licensees, but also leases infrastructure from some of them. This should also influence the terms arrived upon during interconnection negotiations.

Lastly, the various threats (threat not to interconnect, threat to withhold interconnection payments and the threat to degrade or increase the price of non-termination services) should not be viewed in isolation from one another. Even if a particular threat does not constitute a credible threat on its own accord, a combination of threats coupled with skewed market shares in both the purchasing and selling of call termination minutes would translate into a credible enough threat to determine the outcome of a particular interconnect agreement.

Importantly, the CBP possessed by the larger licensees (fixed and mobile) is of such a magnitude that negotiations between the larger licensees and the smaller licensees (such as Cell C) will not lead to termination rates that are conducive to the medium- to long-term development of the mobile market. Specifically, the CBP held by the various large operators is of such a magnitude that negotiation between large and small operators will not allow small operators to charge a termination rate that accurately reflects their smaller scale and higher (current) operational cost. Conversely also, the lack of CBP on the side of smaller licensees implies that the termination rates charged by larger licensees may not be set at such a level that allows for smaller licensees to price their off-net call rates so as to effectively grow their customer base and increase competition in the retail call market. This lack of CBP on the part of Cell $C$ was illustrated by the large increases in MTRs imposed on Cell $\mathrm{C}$ by Vodacom and MTN upon its entry into the markets in 2001.

Termination rates determined by negotiation may also be set in such a fashion that the net payments afforded to smaller operators would not be sufficient to supply the necessary funding for an emerging operator to expand its network infrastructure and service delivery capability to such an extent that it could compete effectively with larger operators over the medium to long term. This could be detrimental to the industry as a whole, as effective future competition from an emerging (currently smaller) operator is minimised along with its ability to constrain retail pricing by incumbent operators.

In conclusion, therefore, there are many other factors which should be taken into account in an assessment of market power (or SMP or ESMP) in a two-sided market. Most of these factors relate to the position of a firm in the retail (or call origination) market, but this is exactly the implication of the two-sided nature of the market.

\section{THE POSITION OF A SMALLER MOBILE OPERATOR IN THE MARKET: THE CASE OF CELL C}

In this section we apply the notion of a two-sided market and the assessment of market power in a two-sided market to the case of a small MNO. We consider data available on the position of Cell $C$ in the SA mobile markets in order to illustrate that although Cell $C$ is the only seller of termination services in its termination market, it cannot be deemed to have SMP or ESMP. This is a very important conclusion, as it implies that the same regulatory conditions cannot be applied 
to all MNOs equally, but should relate to the potential abuse of market power. If a firm faces strong competition on one side of the market, it is unlikely to be able to exercise market power on the other side of the market. Imposing stringent regulations on one side (e.g. by regulating termination rates or applying symmetric reductions in MTRs) might not be conducive for effective competition.

Cell C faced high mobile termination rates (MTRs) since its entry in 2001. This was a direct result of the weak bargaining position faced by Cell $C$ in its commercial negotiations with the larger mobile operators (discussed in detail in the previous section on countervailing buyer power). Evidence of the weak position of Cell C is the increase of $515 \%$ in interconnection rates between 1998 and 2001 (before the entry of Cell C in 2010). As reported by Esselaar and Weeks (2008:5):

The unfortunate licensing mess that ensued between 1998 and late 2001 when Cell $C$ was finally licensed just contributed towards the lack of any competitive constraint on the incumbent mobile operators.

High MTRs had a negative effect on the business of Cell C, as they serve as a price floor for offnet calls. A price floor in the off-net retail market reduces the ability of a new entrant in the mobile market to capture market share from incumbent operators. The economic literature explains how large networks can foreclose a new entrant and keep it from gaining market share by using price discrimination: As explained by the ERG/EC (2003:39):

The problem of price discrimination to foreclose the market pertains mainly to the M2M situation. The incumbent operator(s) may foreclose the market by charging a high (above-cost) termination charge to other networks whereas implicitly charging a lower price internally. This leads to high costs for off-net calls for other operators at the wholesale level and thus to high prices for off-net calls at the retail level. On-net calls, on the other hand, are associated with lower costs and thus with lower retail prices. Such a price structure creates network externalities ('tariff-mediated network externalities') and thus puts small networks with few participants at a disadvantage. The disadvantage is larger the higher the termination charge and thus the higher the difference between the price of an on-net and an off-net call is.

This issue has also been recognised by ICASA, as explained in its explanatory document (2010a:49):

\begin{abstract}
Above cost wholesale call termination rates are likely to lead to higher off-net retail prices. High off-net retail prices can make it harder for new entrants to compete with more established players. For example, firms with high subscriber bases can potentially gain competitive advantage over less established firms by keeping wholesale call termination rates high and creating large on-net/ off-net pricing differentials. The greater the differential between on-net and off-net retail rates, the more attractive to customers are networks that have relatively more on-net calling opportunities (i.e. larger networks).
\end{abstract}

The growth experienced by Cell $C$ since its entry in 2001 could clearly have been affected by a myriad of factors, such as poor network quality, ineffective marketing or simply bad business decisions. The aim of this paper is not to provide an overall assessment of the management strategies of Cell $C$, but rather to illustrate the fact that high termination rates can be an important stumbling block for a new entrant trying to grow market share. The main concern in this regard is that in an ineffectively competitive environment that is dominated by two large operators (as the case is in South Africa), high terminations rates can be used by the incumbents as a barrier to entry and expansion. 


\subsection{Cell C's on-net off-net call distribution}

Cell C entered the South African mobile market during the course of 2001 and the typical issues experienced by a late entrant (in terms of foreclosure from the off-net market) were also faced by Cell C. TABLE indicates that the majority of outgoing calls of Cell C are still off-net calls. This is no surprise, as Cell $C$ has a small market share.

TABLE 5: Cell C outgoing calls (total)

\begin{tabular}{lccccccc}
\hline & June 06 & Dec 06 & Jun 07 & Dec 07 & Jun 08 & Dec 08 & Jun 09 \\
\hline $\begin{array}{l}\text { On net(total } \\
\text { minutes) }\end{array}$ & $18 \%$ & $17 \%$ & $14 \%$ & $18 \%$ & $22 \%$ & $26 \%$ & $28 \%$ \\
$\begin{array}{l}\text { Off net tot mobile } \\
\text { (total minutes) }\end{array}$ & $65 \%$ & $66 \%$ & $68 \%$ & $65 \%$ & $62 \%$ & $59 \%$ & $57 \%$ \\
$\begin{array}{l}\text { Off net to fixed } \\
\text { (total minutes) }\end{array}$ & $17 \%$ & $17 \%$ & $18 \%$ & $17 \%$ & $16 \%$ & $15 \%$ & $15 \%$ \\
\hline
\end{tabular}

\section{Source: $\quad \mathrm{Ce} / \mathrm{C}$}

It is interesting, though, that as Cell $\mathrm{C}$ has managed to grow its market share there has been a reduction in the percentage of off-net calls relative to on-net calls. We do not have updated data for Vodacom, but 2007 data (Esselaar \& Weeks, 2008:6) shows that Vodacom had around $65 \%$ on net and $35 \%$ off-net calls. Clearly this situation creates tariff-mediated network effects that serve to entrench the position of the incumbents.

\subsection{Cell C's subscriber composition}

The ICASA explanatory note (2010a:11) shows that, based on connection data, the SA mobile market has $16 \%$ contract and $84 \%$ pre-paid clients, while in terms of revenue contract subscribers contribute $55 \%$ and pre-paid $45 \%$.

FIGURE 1 clearly shows the difficulties Cell $C$ experienced in entering the more lucrative contract market. It also indicates that while Cell $C$ had managed to grow its contract subscribers to a relatively high percentage during 2006 and 2007, this relative percentage has declined since then. In order for an MNO to become more profitable it has to grow its share of the contract market and show the breakdown of pre-paid vs. contract customers for Cell C. When observing these two figures one can see that contract customers generally come from the higher LSM groups. 


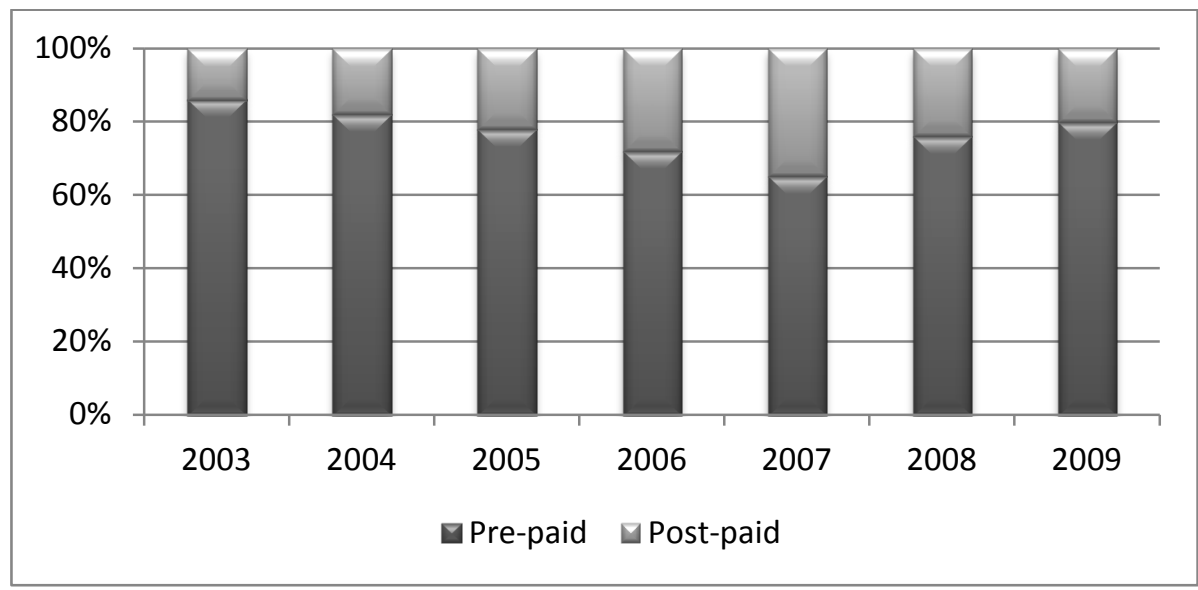

FIGURE 1: Cell C customer base: prepaid and contract contributions (percentage)

Source: CellC(2010)

\subsection{Cell C market shares and costs}

Finally it is important to take into consideration that Cell $C$ cannot reap benefits of scale if it has such a low market share. As stated by the ERG (2008:89):

Putting aside the fixed costs incurred by any given operator, a recent MNO cannot from the start have a comparable customer base to his existing counterparts... However, in the short run, the new coming MNO does not benefit from comparable economies of scale and efficiency since it is has fewer customers. As a result, NRAs may observe that the late entrant incurs a higher per unit cost for all services (including termination) than its competitors (if costs are allocated across lifetime volumes then this effect will potentially be more limited).

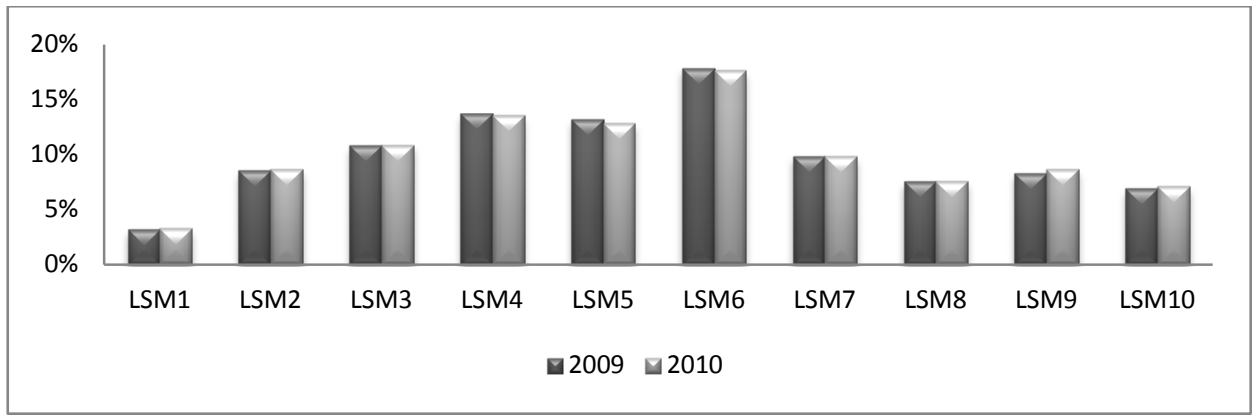

\section{FIGURE 2: Cell C pre-paid customers by LSM group}

Source: CellC (2010)

Economies of scale are not synonymous with efficiency. ICASA appears to argue that Cell C's low market share is the result of inefficiency. However, as ERG (2008:89) points out, even the most efficient firm can still have high unit costs because of lack of economies of scale.

When cost differences exist between operators, symmetric MTRs should not be considered appropriate. The relationship between market share and cost and its impact on the 
effectiveness of MTR interventions are elucidated by Economides, Lopomo and Woroch (2007). These authors consider a model where the regulator does not set MTRs but only enforces a reciprocity rule requiring MNOs to negotiate MTRs that are symmetric. Their results suggest that, under fairly general assumptions, negotiations will usually lead to MTRs close to cost.

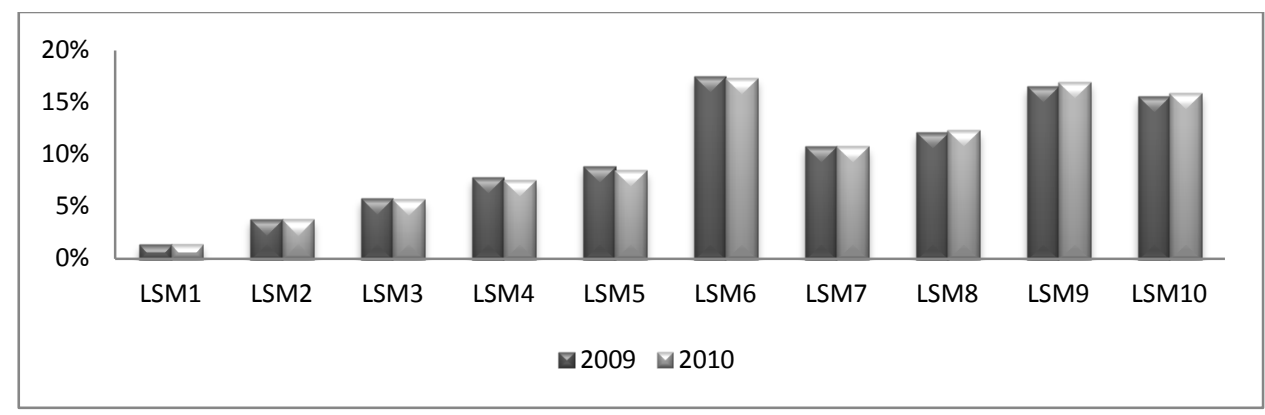

\section{FIGURE 3: Cell C contract customers by LSM group}

Source: Cell C (2010)

More specifically, the authors show that, under conditions of symmetry in costs for two MNOs, reciprocity of MTRs will result in optimal consumer welfare. However, their model also shows that reciprocity in MTRs will not be conducive to competition or higher consumer welfare when cost differences exist between the different MNOs. Under conditions of cost differences, their model suggests that reciprocity of mark-up over termination costs, rather than reciprocity of actual MTRs, must be enforced.

\section{CONCLUSION}

In this paper, we argue that the economic concepts of relevant markets and market power have to be adapted in the case of two-sided markets. We show that in two-sided markets where the price structure is more important than the actual price level, one cannot use the usual indicators to assess whether market power exists. We show that mobile termination markets are indeed two-sided markets consisting of call termination on the one hand and call origination on the other.

Although a strict application of the usual market definition tests may indicate that call termination is a separate market, it does not necessarily follow that in a two-sided market the only seller of termination services possesses market power. We then apply these concepts to the recent announcements by ICASA that it wants to reduce mobile termination rates by regulation, more specifically by introducing a symmetric glide path for reductions in MTRs. We show that the concepts of SMP and ESMP are not based on sound economic principles. When determining SMP regulatory authorities suggest that other criteria (apart from market shares) be used. This has also been incorporated into the ECA. However, when ICASA introduces ESMP in its attempt to regulate MTRs, it bases this largely on market shares.

In analysing data on Cell C - the late entrant in the SA mobile market - we show that what is important is to consider competitive conditions at the retail level. One cannot analyse one side of a two-sided market (termination) in isolation. 


\section{LIST OF REFERENCES}

Caillaud, B. \& Jullien, B. (2003). Chicken \& egg: competition among intermediation service providers. Rand Journal of Economics, 34(2), pp. 309-328.

Economides, N., Lopomo, G. \& Woroch, G. (2007). Strategic commitments and the principle of reciprocity in interconnection pricing. In G. Madden (ed.), The Economics of Digital Markets. Cheltenham, UK: Edward Elgar.

ERG (2008). ERG's Common Position on symmetry of fixed call termination rates and symmetry of mobile call termination rates. Available:

http://www.erg.eu.int/doc/publications/erg_07_83_mtr_ftr_cp_12_03_08.pdf. (Accessed 23 March 2011).

$\varepsilon R G / \varepsilon C$ (2003). Consultation document on a Draft joint $\varepsilon R G / \varepsilon C$ approach on appropriate remedies in the new regulatory framework. 21/11/2003. Available:

http://www.erg.eu.int/doc/publications/erg0330_draft_joint_approach_on_remedies.pdf.

(Accessed 23 March 2011).

Esselaar, S. \& Weeks, K. (2008). The case for the regulation of call termination in South Africa: and economic evaluation. Available: http://web.wits.ac.za/NR/rdonlyres/FE15E972-D8B1-4812-A6351539D99C74F3/0/WeeksEsselar_Mobile_Termination_v13.pdf. (Accessed 23 March 2011).

European Commission (2002). Commission guidelines on market analysis and the assessment of significant market power under the community regulatory framework for electronic communications networks and services. Official Journal of the European Communities, (2002/C 165/03), pp. 66-31.

Geroski, P.A. (1998). Thinking creatively about markets. International Journal of Industrial Organisation, 16, pp. 677-695.

ICASA (2010a) Explanatory Note for the Draft Call Termination Regulations. ICASA Wholesale Call Termination Market Review for the period 2010-2013, pp. 13-32. Available:

http://thornton.co.za/resources/33698_1015.pdf. (Accessed 23 March 2011).

ICASA (2010b) Notice of 2010. "Call Termination Regulations" Pursuant to section 67 (4) of the Electronic Communications Act No. 36 of 2005, pp. 3-12. Available:

http://thornton.co.za/resources/33698_1015.pdf. (Accessed 23 March 2011).

Massey, P. (2000). Market Definition and Market Power in Competition Analysis: Some Practical Issues. The Economic and Social Review, 31(4), pp. 309-328.

Motta, M. (2005). Competition Policy - Theory and Practice. London: Cambridge University Press.

Oftel (2002). Oftel's market review guidelines: criteria for the assessment of significant market power, pp. 1-18.

Rochet, J. \& Tirole, J. (2003). Platform Competition in two sided markets. Journal of the European Economics Association, 1(4), pp. 990-1209.

Valetti, T. (2006). Mobile call termination: a tale of two sided markets. Communications \& Strategies, 61(1), pp. 61-77.

Wright, J. (2004). One-sided logic in two sided markets. Review of Network Economics, 3(1), pp. 4464. 


\section{APPENDIX}

1. The SSNIP (small but significant non-transitory increase in price) test represents a thought experiment in which the competition analyst defines the relevant geographic market by considering whether the firm under investigation is capable of maintaining a small price increase of $5 \%-10 \%$ for a twelve-month period (for example) without a reduction in profits. It starts with the product being sold by the firm under investigation. If the firm's profits are ultimately adversely affected by the price increase, the product market is too narrow. Consequently, a broader product market can be defined by including the closest substitute to which consumers are likely to switch following the price increase. The thought experiment is repeated and other substitutes are added until a broad enough product market has been defined in which the firm under investigation could raise prices on a profitable and sustainable basis. A similar exercise can be carried out for the delineation of the geographic market. 
Theron \& Van Eeden 